\title{
A CLAIM OF HIGH LEVEL GRANITIZATION REFUTED
}

\author{
C.J. Hughes and M.M. Smith \\ Geology Department, Memorial University of Newfoundland \\ st. John's, Newfoundland, CANADA AlB $3 \times 5$
}

\begin{abstract}
Poorly lithified Upper Devonian conglomerates do not exhibit a gradational granitized contact with the high level Belleoram quartz monzonite pluton in southem Newfoundzand as previously maintained, and there is no prima facie case for previously suggested granitization by massive magmatic vapour transport.
\end{abstract}

\section{INTRODUCTION}

Although the topic of granitization no longer excites the same passions as it did a decade or two ago ( $c f$ Read 1957), in part because its processes are now more widely understood (see, for example, Hutchison 1970), it is nevertheless interesting to examine claimed examples of unusual high level granitization phenomena, legitimate to question them, and important to refute them if they should appear to be untenable.

From time to time instances of the operation of "granitization" or "transformation" processes at a high crustal level in anorogenic terrain have been claimed and have commonly been refuted. A well known example was the alleged in situ transformation of granodiorite, basic flows, sills, and pyroclastic rocks within the Slieve Gullion complex, Northern Ireland, during Tertiary igneous activity as claimed by Reynolds (1950, 1951), and discussed and modified by Bailey and McCallien (1956). Another instance from the British Tertiary province was the alleged transformation of Precambrian arkoses at their contact with a large Tertiary granophyre intrusion in the Isle of Rum, Scotland as claimed by Black (1954) and refuted by Hughes et al (1957). These instances are, of course, exclusive of granitization and migmatite development in metamorphic belts where geothermal gradients were apparently abnormally high, such that high regional metamorphic temperatures were attained at comparatively shallow depths as, for example, in the Bosost area of the central Pyrenees (Zwart 1962).

High level granitization phenomena have been claimed by Ermanovics et al (1967) in rejation to contact phenomena around the Belleoram pluton, outcropping on the south coast of Newfoundland in an area only very recently accessible by road.

The Belleoram pluton is composed mainly of a medium-grained gray quartz monzonite (using term as redefined by Streckheisen 1973), outcropping over an area of approximately $150 \mathrm{~km}^{2}$ including the town of Belleoram on the south coast of Newfoundland. A detailed account of the pluton with references to earlier work is given by Ermanovics et al (1967), an account of the regional geology of an area including the eastern half of the pluton is given by Williams (1971), and geochemical data on the Belleoram pluton and other granitoid rocks of eastern Newfoundland are given by Strong et al (1974). Generally steep contacts against hornfelsed Lower Palaeozoic sedimentary rocks occur around most of the western, northern and eatern margins of the Belleoram pluton.
On its southern margin, however, where the pluton is in contact with gently dipping arkosic conglomerates of the Upper Devonian Great Bay de I'Eau Formation, the contact although not well exposed is, judging by the intersection of its position with topography, probably inclined overall at a low angle to the south. The pluton lacks any apparent fabric whether igneous or metamorphic. A revised preliminary $K$-Ar age determination on biotite from the intrusion (Wanless et al 1967) of $342 \pm 20 \mathrm{~m} . \mathrm{y}$. suggests a late Devonian or early Carboniferous age for the pluton which is among the youngest known granitic intrusions in Newfoundland. An episonzal setting for the emplacement of the pluton is strongly indicated not only by its structural features but also by the small age difference between it and the Upper Devonian sediments, unindurated away from the contact zone, that it intrudes.

Ermanovics et al (1967) describe in some detail allochemical contact phenomena, assimilation, and autometasomatism within the intrusion. These points, which are well taken by the writers, constitute a timely warning to those petrologists who, lulled by the homogeneous appearance of many granite outcrops, indulge in simplistic models of petrogenesis and differentiation such as fractional crystallization based on chemical data. However, the lengthy description specifically of a "completely gradational contact" with the arkosic conglomerates of the Great Bay de l'Eau Formation accompanied by granitization phenomena prompted our investigation as granitization phenomena at such a high crustal level would be unusual and significant.

While recognizing that the "stock is of magmatic origin", Ermanovics et al (1967) present data to show that the "arkosic conglomerates near the stock have been altered to rocks of granitic composition". Furthermore they claim that "the adamellite - conglomerate contact is completely gradational". They then proceed to surmise that "these results can be explained by degassing of the intrusion through the conglomerate", whereby "the magmatic vapour phase could transport soda, potash, alumina, and silica, in amounts sufficient to explain the observed compositional variation", and that "such local granitization proceeds by vapour phase exchange of material between host rock and intrusion combined with mechanical assimilation of the host by the intrusion".

Clearly something unusual could well have occurred at the contact of a large high-level quartz monzonite pluton with a roof of unindurated conglomerate. A re-examination of the area of the contact shows however that the observations upon which the hypothesis 


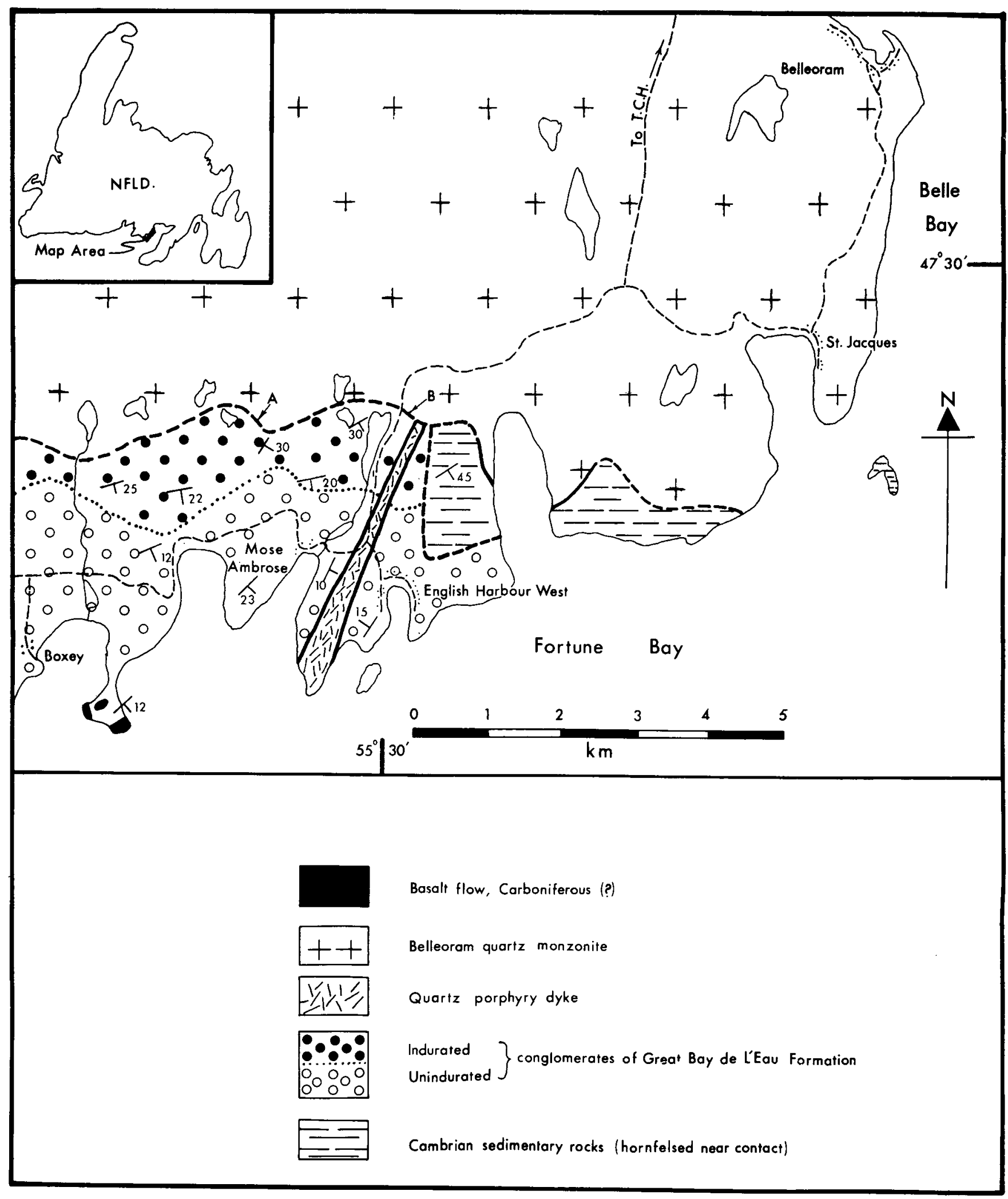

FIG. I Geological sketch map of the southeastern portion of the Belleoram pluton and country rocks based on Ermanovics et al. (1967) and Smith (1976). 
of high level granitization is based are in part incorrect and, with necessary factual corrections, are all capable of supporting a credible, consistent, and less sensational explanation in terms of an unexceptional thermal metamorphism at a high crustal level with little or no evidence of granitization.

\section{THE FIELD EVIDENCE}

The arkosic conglomerate changes markedly in appearance from a regionally unindurated red rock (breaking around pebbles and cobbles) to a highly indurated gray rock (breaking across pebbles and cobbles) near to its contact with the intrusion. A prominent zone of such gray rock can be mapped up to some $1200 \mathrm{~m}$ in outcrop width. Given the southerly slope of the terrain towards the coast and an inferred southerly inclination of the underlying contact with the intrusion, the true thickness of indurated gray conglomerate could obviously be a small fraction only of this figure of $1200 \mathrm{~m}$. However, there is nothing in the field appearance of the indurated gray conglomerate to suggest anything other than "baking" such as would be anticipated in the aureole of a large pluton.

When the contact is walked out, fair exposure generally permits the position of the contact to be narrowed down to within a few tens of metres but only in one place, locality $A$ in Figure 1, was it actually seen. There the intrusion exhibits a sharp intrusive discordant contact dipping $70^{\circ}$ to the south against conglomerate which strikes $\mathrm{N} 25^{\circ} \mathrm{E}$ and dips at $30^{\circ}$ to the southeast. At locality $B$ in Figure 1 the contact can be narrowed down to within two metres; there too it appears to be discordant and the conglomerate and quartz monzonite are readily distinguishable.

\section{THE PETROGRAPHIC EVIDENCE}

Rocks belonging to the intrusion collected at or close to the contact at the two localities referred to above retain a medium grained grey appearance but in thin section can be seen to differ from the average rock of the intrusion by having a matrix between plagioclase grains that is crudely granophyric. These marginal rocks are also relatively poorer in alkali feldspar and contain some clinopyroxene whereas in the more central parts of the intrusion biotite, hornblende, and deuteric alteration products constitute the dark mineral assemblage. These features are unexceptional and can be matched in other epizonal plutons (for example Hughes 1969, pp. 123 to 125 and p. 138), where volatile constituents are considered to have been retained during crystallization.

The indurated gray arkosic conglomerate collected from several localities at or near the contact shows in thin section no obvious change in the appearance of feldspar, but quartz grains, whether constituting large clastic grains or components of granite clasts, show a prominent recrystaliization to finergrained monomineralic aggregates with sutured maxgins that preserve the outline of the original grains. The matrix develops a fine grained granoblastic texture composed mainly of quartz together with some feldspars, magnetite (taking the place of haematite in the unindurated red conglomerate), occasional small shreds of biotite, and scattered concentrations of granules of diopside reflecting an originally locally calcareous matrix. Furthermore, minerals such as sericite, epidote, chlorite, and actinolite, stable under conditions of high $P$ (H2) and characteristic of the envelope surrounding 20 porphyry copper intrusions for example, are conspicuous by their absence from the contact metamorphosed conglomerate. The petrographic evidence is thus consistent with an isochemical thermal metamorphism without recourse to hypotheses of granitization, vapour phase exchange, and gradational contacts.

\section{THE COMPOSITIONAL EVIDENCE}

The writers have not undertaken further analytical work, but would like to offer some comments on the data presented by Ermanovics et al (1967) with particular reference to the alleged systematic change in composition of the conglomerate towards the contact.

The conglomerate contains clasts comonly up to $5 \mathrm{~cm}$, more rarely up to $20 \mathrm{~cm}$ in size. The clasts comprise locally derived granite, granophyre, rhyolite, quartzite, and siltstone, together with some milky quartz; granitic material predominates. Not only does the formation show considerable lateral variation in clast composition related to older bedrock lithologies throughout the area of its outcrop (Williams 1971), but it is apparent that in the immediate area under discussion adjacent to the contact with the Belleoram pluton there may exist also a vertical stratigraphical variation in composition. Scattered outcrops and the massive nature of the beds coupled with some minor flexuring precluded establishment of an intraformational stratigraphy. However, it is clear, for example, that some thick layers in the succession contain prominent large quartz clasts and thus will likely have a higher silica content than beds without such clasts.

Ermanovics et al record modal variation in 17 samples of conglomerate and the chemical composition of two bulk samples of conglomerate, one unaltered, one indurated. The samples collected for modal analysis were related to the position of the contact by assuming the latter to be planar and dipping to the south at 4 . The extrapolations involved in this assumption (Ermanovics et al 1967, Table 2) become dangerous, even preposterous, particularly in view of the actually observed locally steeply dipping and discordant contact. For example, a sample collected no less than $150 \mathrm{~m}$ horizontally away from the contact is assumed by them to be the closest to the contact and to overlie it at a depth of only $1.6 \mathrm{~m}$. Far more likely what Ermanovics et al have achieved by their geometrical construction is a crude representation of an original upward modal variation within the Great Bay de l'Eau Formation itself which does indeed have an overall component of dip to the south. Moreover, to base conclusions on metasomatism on but two analysed samples (however large they may be and thus representative of the immediate layer from which they were obtained) is similarly unwarranted as the difference in silica contents of the two samples, 
$81.7 \%$ versus $77.0 \%$, and in other oxides could also readily be explained by clast lithology.

\section{CONCLUSION}

There is a sharp contact between the Belleoram quartz monzonite and the arkosic conglomerate of the Great Bay de l'Eau Formation thus refuting a previous claim of a gradational contact between the two rock units. Field and petrographic evidence are consistent with an unexceptional high level thermal metamorphism, available compositional data do not make any prima facie case for metasomatism, and there are thus no grounds for invoking granitization.

\section{ACKNOWLEDGEMENTS}

The writers wish to record their appreciation of advice and logistical help from Bryan A. Greene, Department of Mines and Energy, St. John's. The field work on which this reinterpretation is based was carried out mainly by one of us (MMS). and an account of it forms a part of a MUN B.Sc. Honours Dissertation (Smith, 1976). Support for both writers from NRC Operating Grant $A-4225$ is gratefully acknowledged.

\section{REFERENCES}

BAILEY, E.B. and MCCALIIEN, W.J. 1956. Composite minor intrusions, and the slieve Gullion complex, Ireland. Liverpool and Manchester Geol. Journ., 1. pp. 466-501.

BLACK, G.P. 1954. The acid rocks of western Rhum. Geol. Mag., 91, pp. 257-272.

ERMANOVICS, I.F., EDGAR, A.D. and CURRIE, K.I. 1967. Evidence bearing on the origin of the Belleoram stock, southern Newfoundland. Can. J. Earth Sci., 4, pp. 413-431.

HUGHES, C.J. 1960. The Southern Mountains igneous complex, Isle of Rhum. Quart. J. Geol. Soc. London, 116, pp. 111-138.
HUTCHISON, W.W. 1970. Metamorphic framework and plutonic styles in the Prince Rupert region of the central Coast Mountains, British Columbia. Can. J. Earth Sci., 7, pp. 376-405.

READ, H.H. 1957. The granite controversy. Murby, London, $430 \mathrm{pp}$.

REYNOLDS, D.I. 1951. The geology of Slieve Gullion, Foughill, and Carrickearnan: an actualistic interpretation of a Tertiary gabbro-granophyre complex. Trans. Roy. Soc. Edinburgh, 62, pp. 85-142.

SMITH, M.M. 1976. Geology of an area around Mose Ambrose and English Harbour West, South Coast Newfoundland. B.Sc. Honours Thesis, Memorial University of Newfoundland, $38 \mathrm{pp}$.

STRECKHEISEN, A.I. 1973. PIutonic rocks: classification and nomenclature recommended by the IUGS subcomision on the systematics of igneous rocks. Geotimes, 18, pp. 26-30.

STRONG, D.F., DICKSON, W.I., O'DRISCOLI, C.F. and KEAN, B.F. 1974. Geochemistry of eastern Newfoundland granitoid rocks. Newfoundland Dept. Mines Energy Report 74-3, 140 pp.

WANLESS, R.K., STEVENS, R.D., LACHANCE, G.R. and EDMONDS, C.M. 1967. Age determinations and geological studies. K-Ar isotopic ages, Report 7. Geol. Surv. Canada Paper 66-17, $120 \mathrm{pp}$.

WILLIAMS, H. 1971. Geology of Belleoram map-area, Newfoundland (IM/1I) Report and Map 1323A. Geol. Surv. Canada Paper 70-65, 39 pp.

ZWART, H.J. 1962. On the determination of polymetamorphic mineral associations and its application to the Bosost area. (Central Pyrenees). Geol. Rdsch., 52, pp. 38-65. 